Asnawi ${ }^{1}$, llham Maulana Saud ${ }^{2}$,

Wiratmanto ${ }^{3}$

1Prodi M anajemen, Fakultas E konomi

dan Bisnis U niversitas M uhammadiyah

Yogyakarta

2Prodi M anajemen, Fakultas E konomi

dan Bisnis U niversitas M uhammadiyah

Yogyakarta

3Prodi IImu H ukum, Fakultas H ukum

U niversitas M uhammadiyah Yogyakarta

Jalan B rawijaya, Tamantirto, K asihan,

Bantul, Yogyakarta 55183

1Email: asnawi_an@umy.ac.id

\section{Peningkatan Mutu Produk dan Pemasaran Olahan Ikan Bandeng}

https:/ / doi.org/ 10.18196/ bdr.5114

\begin{abstract}
As well as micro, small, and medium-scale business in general, business groups engaged in the food processed milkfish also face the problems, especially on the limitations of product quality and marketing. Two businesswomen who pursue food business of milkfish, namely Mrs. Eko with Pindang Bandeng "Warisan" and Mrs. Erni with presto milkfish "Prima". In production aspects, both businesses are still limited because it only meets the society needs and sell at certain moments like, Sunday morning recitation and tiban market. From the results of the pre-survey and interviews can be identified several problems, such as: unavailability of equipment to produce high quality products, unavailability of attractive packaging to enter broader market, unavailability aspect of legality of P-IRT from Health Office for micro food business, lack of entrepreneurship, and the need for more intensive management assistance to enter the wider market. These issues have been assisted by the completion of the following activities: improvement of equipment, package and nameplate, P-IRT certification, training to cultivate entrepreneurship, promotion, and marketing management assistance. Dedication program with IbM scheme has been implemented and produced the output, such as in the form of packaged the processed of milkfish, brochures, business nameplate of Pindang Bandeng and presto milkfish with brand "Warisan" and "Prima", and P-IRT certificates for both partners.

Keyword: product, marketing, processed milkfish
\end{abstract}

\title{
PENDAHULUAN
}

Sejak terjadinya krisis ekonomi di tahun 1997 masyarakat Indonesia sekarang ini dihadapkan pada pilihan untuk melakukan wirausaha. Muncul dan tumbuhnya kelompokkelompok usaha di masyarakat sebagai wujud dari upaya kelompok mikro usaha ini untuk merespon perubahan tersebut. Potensi yang ada cukup besar mengingat usaha mikro kecil ini merupakan usaha yang tidak terkena dampak krisis ekonomi. Peluang usaha untuk kelompok masyarakat masih besar karena untuk mencukupi kebutuhan sehari-hari masih diperlukan pemenuhannya. Disamping itu pemerintah sendiri mempunyai komitmen untuk membina usaha mikro kecil dan menengah (U M KM ) secara menyeluruh. 
Menurut Stel, dkk (2004) menyatakan bahwa U M KM memiliki peran yang sangat penting dalam perekonomian nasional. Peran tersebut terutama pada aspek-aspek seperti pembukaan lapan gan kerja, pemerataan pendapatan, pemban gunan ekonomi pedesaan, dan peningkatan ekspor non migas. Sejalan hal tersebut, U ndang-U ndang Nomor 20 Tahun 2008 menjelaskan bahwa tujuan dari pemberdayaan UM KM adalah untuk mewujudkan stuktur ekonomi perekonomian nasional yang seimbang, berkembang, dan berkeadilan, menumbuh dan mengembangkan kemampuan usaha mikro, kecil dan menengah menjadi usaha yang tangguh dan mandiri, meningkatkan peran mikro, kecil dan menengah dalam pemban gunan daerah, penciptaan lapangan pekerjaan, pemerataan pendapatan, pertumbuhan ekonomi dan pengentasan rakyat dari kemiskinan.

Untuk mencapai tujuan pemberdayaan U M KM tersebut, Bank Indonesia (2011) mengemban gkan strategi fivefinger philosophy, yaitu (1) jari jempol, mewakili peran lembaga keuangan untuk memberikan pinjaman/ pembiayaan kepada nasabah mikro, kecil dan menengah serta sebagai agents of development; (2) jari telunjuk, mewakili pemerintah dan Bank Indonesia yang berperan dalam regulator sektor riil dan fiskal, menerbitkan izinizin usaha, mensertifikasi tanah sehingga dapat digunakan oleh U M KM sebagai agunan, menciptakan iklim yang kondusif dan sebagai sumber pembiayaan; (3) jari tengah, mewakili katalisator yang berperan dalam mendukung perbankan dan U M KM , termasuk Promoting Enterprise A ccess to $C$ redit (PEAC) U nits, perusahaan penjamin kredit; (4) jari man is, mewakili fasilitator yang berperan dalam mendampingi U M KM , khususnya usaha mikro, membantu U M KM untuk memperoleh pembiayaan dari bank atau sumber lain, (5) jari kelingking, mewakili U M KM yang berperan dalam pelaku usaha, pembayar pajak dan pembukaan tenaga kerja. Sudaryanto, dkk (2013) berpendapat bahwa five finger philosophy ini membentuk suatu sinergi yang saling mengguntung tidak hanya bagi U M KM dan pemodal (bank atau non bank), tetapi juga bagi masyarakat, dan pemerintah berupa ketersediaan lapangan kerja bagi masyakat dan meningkatnya Pendapatan D omestik Bruto (PDB).

Secara praktik U M KM sering dikaitkan dengan usaha yang memiliki keterbatasan modal. Tidak jarang pula jen is usaha ini seringkali dikaitkan dengan bisnis ala rakyat kecil atau wong cilik. Namun juga tidak sedikit yang berawal dari U M KM ini kemudian berubah menjadi perusahaan yang maju. Karena merupakan bisnis kecil maka aspek produksi dari U M KM ini juga menggunakan metode dan teknologi yang sederhana dan masih menggunakan manajemen yang sederhana pula. Dari aspek produksi biasanya menggunakan rumah sendiri sebagai tempat usahanya dan dari segi manajemen tidak 
ada perencanaan dan kontrol kualitas. Disamping itu biasanya juga belum berbentuk badan usaha dan aspek legalitas juga masih lemah. M ereka dalam menawarkan produknya juga masih dalam kemasan yang seadanya.

Persoalan utama dari U MKM tersebut terutama pada sumber daya yang dimiliki. Kelompok usaha U M K M terutama yang mikro kecil tidak mempunyai sumber daya yang berlebih, baik dari segi permodalan, kapasitas produksi dan manajemen. A gar usaha yang tergolong mikro ini dapat berkembang maka perlu adanya dorongan dari luar untuk melakukan akselerasi. Kegiatan yang sifatnya pelatihan dan pendampingan manajemen sangat dibutuhkan oleh kelompok usaha ini, disamping pemenuhan legalitas dan pemasaran.

Kegiatan yang sifatnya pelatihan dan pendampingan bagi U M KM ini penting dilakukan karena untuk membantu pemerintah dalam upaya pemberdayaan dan pertumbuhan U M KM . H adiyati (2011) mengemukaan bahwa pemerintah telah menghasilkan dua program strategis untuk pemberdayaan dan pertumbuhan UMKM, yaitu program kewirausahaan dan program kemitraan. Program kewirausahaan diharapkan menjadi basis dalam pengemban gan sumber daya manusia sebagai pelaku U M KM . Pengemban gan sumber daya manusia kepada mitra U M KM dapat dilakukan dalam bentuk pelatihan dan pendampingan.

\section{PERMASALAHAN MITRA}

Kelompok usaha yang perlu memperoleh dorongan dari luar berupa pelatihan dan pendampingan usaha ini termasuk di dalamnya adalah kelompok usaha yang mengolah bahan makanan dari ikan bandeng. A da dua orang ibu yang menekuni usaha makanan dari ikan bandeng ini, yaitu Ibu Eko Sayektiningsih berupa pindang bandeng berlabel Pindang Bandeng Presto "Warisan" dan Ibu Erni Siwi Karyanti yang berlabel bandeng presto "Prima" secara pangsa pasar memiliki peluang yang cukup besar. Namun, dari segi aspek produksi kedua usaha tersebut masih terbatas karena hanya untuk memenuhi di sekeliling lokasi usaha dan juga dipasarkan pada momen-momen tertentu antara lain arisan ibu-ibu, pengajian minggu pagi, pasar tiban, dan sebagainya. O leh karenaitu, untuk memperluas cakupan pangsa pasarnya, kegiatan pendampingan pemasaran dirasa perlu untuk dilakukan dengan tujuan agar produk ini lebih dikenal konsumen, dan dapat menginformasikan keunggulan sebuah produk usaha.

$M$ anajemen usaha yang dilakukan juga masih sederhana, belum adanya perencanaan usaha yang baik dan berproduksi sesuai dengan permintaan konsumen. Sebagaimana 
yang dialami oleh usaha mikro lainnya, dalam melakukan produksi pun belum ada rutinitas dan tidak didasarkan pada standar kualitas tertentu. M eskipun tidak ada komplain dari konsumen tetapi kedua ibu tersebut merasa kurang percaya diri untuk memasarkan secara lebih luas lagi. O leh karena itu, kegiatan yang sifatnya pelatihan dan pendampingan manajemen sangat dibutuhkan oleh kelompok usaha ini tujuan dari kegiatan ini agar kelompok usaha tersebut memiliki jiwa kewirausahaan yang tangguh. Jong dan Wennekers (2008) menjelaskan kunci dari kesuksesan kewirausahaan adalah berani mengambil risiko, menjalankan usaha sendiri, memanfaatkan peluang-peluang, menciptakan usaha baru, pendekatan yang inovatif, mandiri, tidak bergantung pada bantuan pemerintah.

Produk makanan dari ikan bandeng ini sebagai usaha masyarakat calon pengusaha, diproduksi oleh industri rumah tangga yang sederhana. Dalam penyajian produk juga masih menggunakan alat yang sederhana dan belum ada brand atau merek untuk menengarai produk tersebut. W ujud dari makanan ini dikemasdengan plastik sederhana dan tidak tahan lama.

$\mathrm{H}$ ingga sekarang ini kedua ibu tersebut dalam menjual produknya tidak memakai label atau nama produk, hanya dibungkus dengan menggunakan plastik atau kardus. Peralatan yang dipakai juga masih sederhana yaitu berupa panci presto dan kompor pemanas, belum ada papan nama yang menunjukkan lokasi, aspek legalitas juga belum ada.

Berdasarkan dari hasil survei awal dan wawancara serta analisis situasi, terdapat beberapa permasalahan yang dihadapi mitra, yaitu:

1. Situasi Internal

a. Belum tersedianya logo, desain kemasan, dan brosur yang menarik untuk memasuki pasaran yang lebih luas lagi.

b. Belum tersedianya aspek legalitas dari Dinas Kesehatan yang berupa P-IRT untuk usaha mikro makanan.

c. Belum tersedianya peralatan yang baik untuk menghasilkan produk yang lebih berkualitas.

d. Belum mempunyai jiwa kewirausahaan yang tangguh.

\section{Situasi Eksternal}

a. Produk ikan bandeng mitra belum dikenal secara luas oleh masyarat, sehingga perlunya pendampingan manajemen yang lebih intensif untuk dapat menembus pasar yang lebih luas. 
Berdasarkan hasil analisis permasalahan mitra U M KM di atas, maka tujuan dari program pengabdian kepada masyarakat ini adalah untuk memberikan pendampingan dalam upaya peningkatan mutu produk dan pemasaran ikan bandeng, bentuk kegiatan pendampingan yang dilakukan adalah peningkatan peralatan, kemasan dan papan nama, pembuatan sertifikat P-IRT, pelatihan untuk menumbuhkan jiwa kewirausahaan, promosi yang lebih intensif, dan pendampingan manajemen pemasaan.

\section{METODE PELAKSANAAN}

U ntuk mengatasi permasalahan tersebut diperlukan solusi yang dapat bermanfaat bagi kedua mitra UMKM tersebut dan telah disepakati bersama oleh Ibu Eko Sayektiningsih dan Ibu Erni Siwi Karyanti. Solusi yang dipakai untuk mengatasi permasalahan kedua mitra tersebut adalah pemberdayaan dan pendampingan manajemen. Pemberdayaan melalui pembuatan logo dan desain kemasaran yang lebih menarik, peningkatan peralatan dan kemasan, pemenuhan aspek legalitas sertifikasi P I RT (PanganIndustri Rumah Tangga) dari Dinas Kesehatan Kabupaten Kulon Progo dan Kabupaten Sleman, pelatihan berupa sarasehan kewirausahaan, dan pendampingan manajemen pemasaran ke berbagai toko swalayan yang dilengkapi dengan brosur produk olahan ikan bandeng.

\section{HASIL DAN PEMBAHASAN}

Kegiatan pengabdian kepada masyarakat tentang peningkatan mutu produk dan pemasaran olahan ikan ban deng dengan skema IbM ini telah selesai dilaksanakan. H asil yang dicapai dari kegiatan-kegiatan tersebut sudah sesuai dengan perencanaan dari tujuan pengabdian masyarakat ini dan bermanfaat bagi mitra U M KM. Setelah melalui sinergi dengan I bu Eko Sayektiningsih dan Ibu Erni Siwi Karyanti sebagai pemilik usaha olahan ikan bandeng "W arisan" dan "Prima" maka dari segi promosi telah dihasilkan beberapa produk antara lain desain logo kemasan yang menarik, brosur/ leaflet untuk menunjang pemasaran, dan papan nama.

\section{Desain Logo Kemasan}

A gar produk olahan bandeng dapat dipasarkan dengan baik maka perlu kemasan yang menarik. Setelah melalui diskusi yang mendalam dengan kedua mitra maka hasil akhir desain logo kemasan olahan ikan bandengini dapat dilihat pada gambar 1 . A danya logo kemasan ini dapat menjadikan identitas produk mitra sehingga lebih mudah dikenal dan dingat oleh masyarakat. 


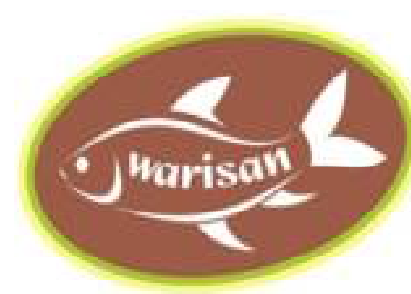

Gambar 1. Desain Logo

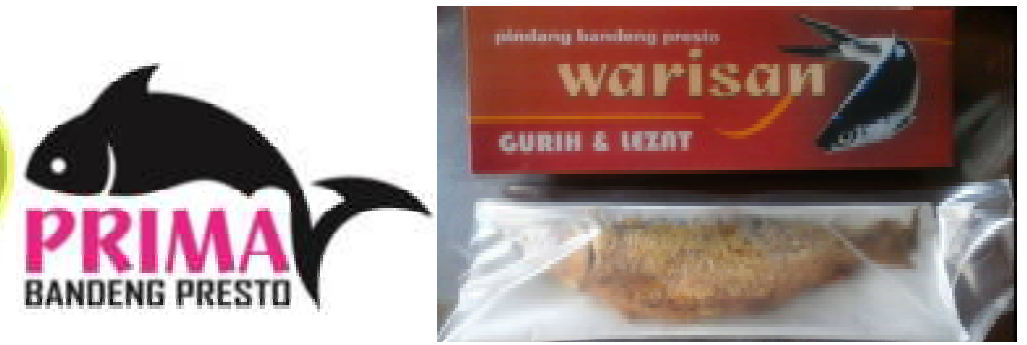

Gambar 2. Desain Kemasan

2. Pembuatan Brosur/leaflet

A gar produk olahan ikan bandeng ini dapat dikenal oleh masyarakat luas diperlukan adanya media promosi yang bisa menyampaikan keistimewaan dari produk tersebut. Sehubungan dengan hal itu telah dibuat leaflet atau brosur yang menarik untuk menggugah calon pembeli. Pembuatan brosur ini dilakukan dengan melalui diskusi dan sekaligus praktek pembuatan oleh kedua ibu tersebut yang didampingi oleh mahasiswa Jurusan Manajemen U MY. Hasil akhir dari pembuatan brosur tersebut sebagaimana tercantum pada gambar 3 .

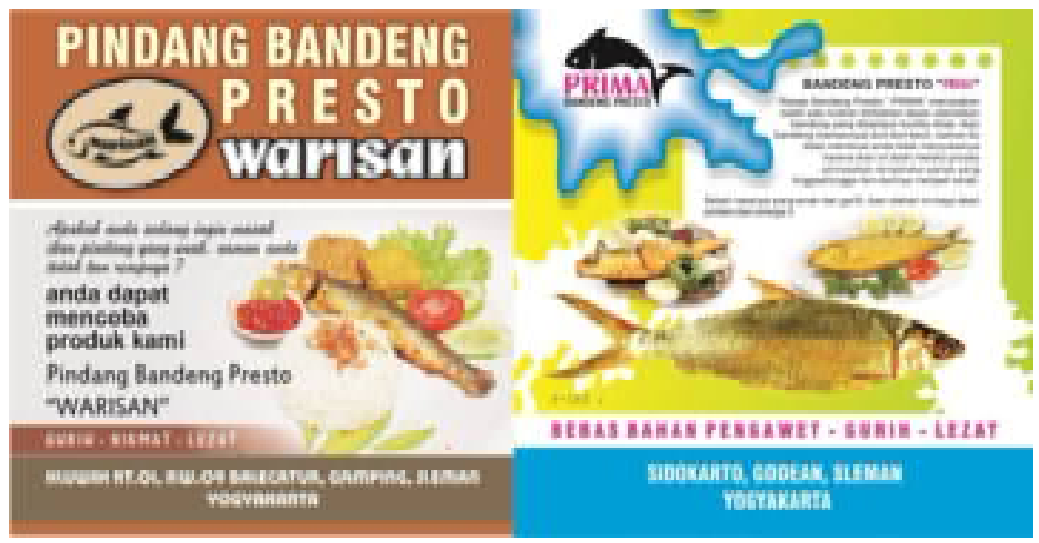

Gambar 3. Brosur Bandeng Presto "PRIMA"

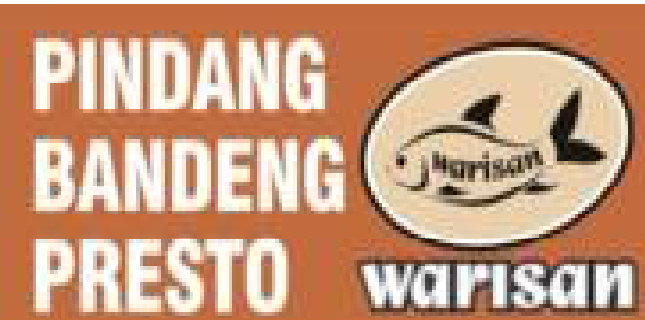

GURIH - NIKMAT = LEZAT

HIUUHн

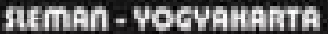

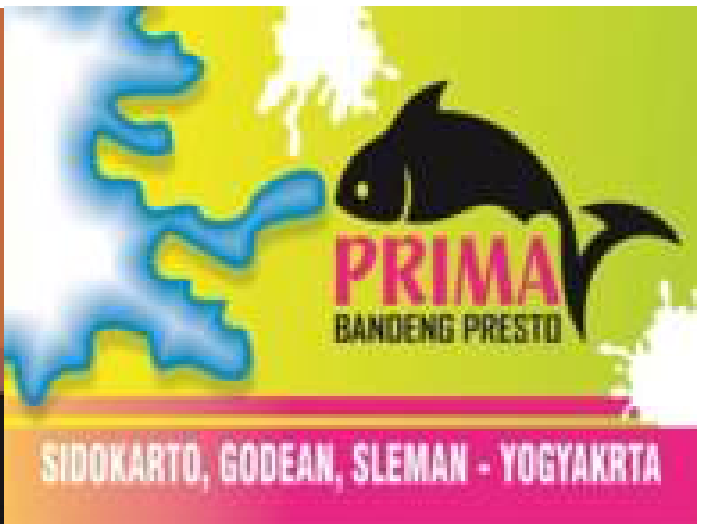

Gambar 4. Papan Nama Bandenga Presto "PRIMA" 


\section{Pembuatan Papan Nama}

Untuk mempermudah pembeli dalam mencari lokasi tempat penjualan olahan bandeng "Warisan" dan "Prima" maka diperlukan papan nama. Papan nama dibuat sejelas mungkin agar calon pembeli mudah mencarinya. Gambar papan nama kedua mitra tersebut bisa dilihat pada gambar 4 .

\section{Sertifikat P-IRT}

Pengurusan sertifikat P-IRT melibatkan pihak Puskesmas dan Dinas Kesehatan, untuk "Prima" sudah memperoleh sertifikat P-IRT lebih dulu, sedangkan untuk "Warisan" baru memperoleh setelah dilakukan uji air dan uji produk. Bukti dokumen tercantum dibawah ini:
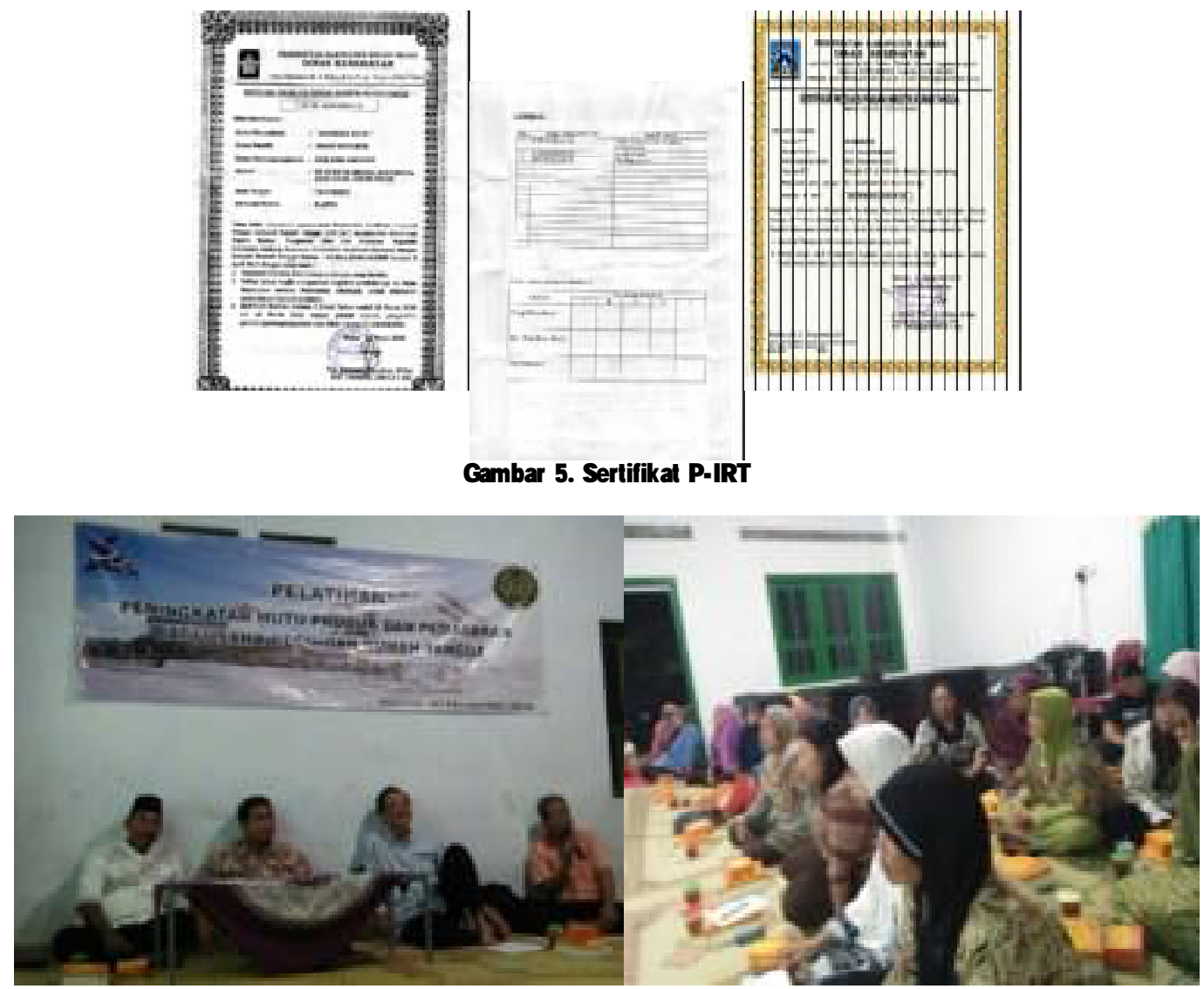

Gambar 6. Pelatihan Kewirausahaan

\section{Sarasehan Kewirausahaan}

Kegiatan ini dalam rangka untuk menumbuhkan jiwa kewirausahaan bagi kedua mitra yang diperluas pada komunitas kuliner yang berada di lingkungan dusun Kluwih. M ateri 
yang disampaikan bernuansa praktis dan mudah dipahami bagi pengusaha rumah tangga. Kegiatan tersebut terdokumentasi pada gambar 6 .

\section{Pemberian Bantuan Peralatan}

Bantuan peralatan kepada kedua mitra dilakukan dalam rangka untuk meningkatkan produksi dan kualitas produk. Peralatan yang berupa panci presto dan vacum sheler serta beberapa peralatan lain diberikan kepada kedua mitra tersebut. Gambar berikut merupakan penyerahan peralatan kepada kedua mitra:

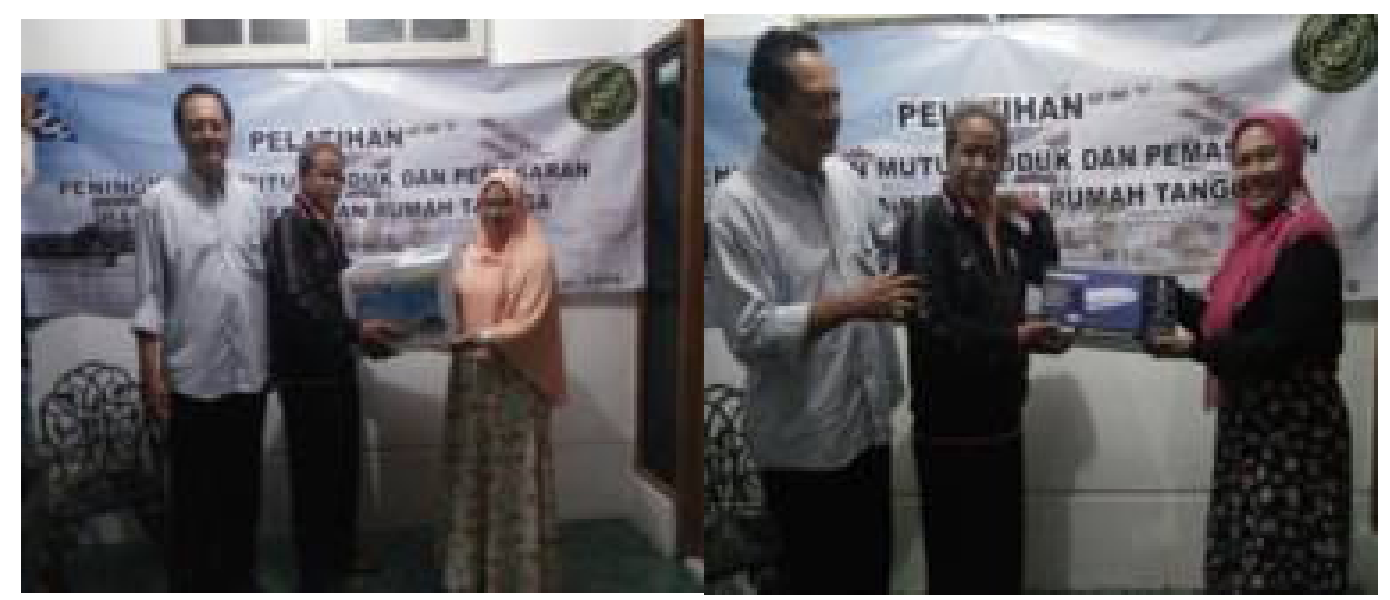

Gambar 7. Pemberian Bantuan Peralatan

\section{Pendampingan Manajemen Pemasaran}

U ntuk menindaklanjuti dari saresehan tentang kewirausahaan maka diperlukan pendampingan manajemen khusus bagi kedua mitra. Pendampingan manajemen dilakukan dengan membuka akses kedua mitra tersebut ke berbagai toko swalayan dan oleh-oleh yan gada di seputaran Sleman dan Kota Yogyakarta. Setelah didampingi kurang lebih 4 bulan maka kedua mitra mampu untuk memperluas pangsa pasar dengan menitipkan produknya di toko oleh-oleh.

A gar usaha makanan bandeng olahan yang dimiliki oleh Ibu Eko Sayektiningsih dan Ibu Erni Siwi Karyanti bisa berkembang, menyerap banyak tenaga kerja dari D esa Bal ecatur dan Sidokarto dan menginspirasi ibu-ibu lainnya untuk memiliki usaha sendiri. Maka diperlukan solusi aspek kemasan dan pengemasan, legalitas, produksi, kewirausahaan dan manajemen pemasaran. Pada aspek kemasan dan pengemasan kegiatan pendampingan yang telah dilakukan adalah pembuatan logo, brosur, dan papan nama. Logo kemasan ini akan menjadikan identitas produk mitra sehingga mudah diingat oleh masyarakat serta sebagai pembeda antara produk-produk ikan bandenglainnya, sedangkan 
pembuatan brosur dan papan nama ditujukan untuk membantu mitra dari segi promosi.

Setelah mitra memliki logo, brosur dan papan nama. Kegiatan pendampingan selanjutnya yang dilakukan adalah desain kemasan dan pengemasan. Kondisi awal kemasan makanan olahan ikan bandeng Ibu Eko Sayektiningsih dan Ibu Erni Siwi Karyanti masih sangat sederhana dan kurang menarik. Setelah adanya pendampingan ini, kemasan produk mitra menggunakan plastik mika dan kardus dan diserta dengan logo produk. Pembuatan logo, brosur, dan kemasan bagus dan menarik ini sangat membantu dan memudahkan bila produk mitra ditawarkan atau dititipkan di mini market, swalayan maupun toko oleh - oleh, sehingga bisa bersaing dengan produk sejenisnya.

Pada aspek legalitas, kegiatan pendampingan yang telah dilakukan adalah pengurusan sertifikat P-IRT yang melibatkan pihak Puskesmas dan Dinas Kesehatan. Tujuan pengurusan sertifikat PJIRT ini adalah untuk melegalkan usaha atau produk mitra. Sesuai dengan five finger philosopy, penerbitan sertifikat PłRT ini merupakan salah satu bentuk pemberdayaan pemerintah terhadap U M KM . Banyak manfaat yang diperoleh oleh mitra dari kegiatan diantaranya adalah kualitas dan keamanan produk mitra akan mendapat kepercayaan dari masyarakat. Selain itu, sertifikat P-IRT ini juga merupakan salah aspek yang disyaratkan oleh mini market, swalayan maupun toko oleh - oleh. Dengan demikian, adanya pengakuan sertifikat P-IRT ini dapat membantu mitra untuk memperluas pangsa pasar produknya.

U ntuk aspek produksi, kegiatan pendampingan yang dilakukan adalah pemberian peralatan terutama bagi I bu Eko Sayektiningsih yang belum menggunakan teknologi presto. Tujuan dari kegiatan ini adalah untuk meningkatkan kualitas dan kuantitas produk ikan bandeng I bu Eko Sayektiningsih. Pemberian modal berapa peralatan kepada mitra ini merupakan salah langkah dalam pemberdayaan UMKM, dan diharapkan dengan suntikan modal berupa peralatan ini mitra dapat lebih produktif dan mampu memenuhi kebutuhan pangsa pasar.

U ntuk meningkatkan motivasi dan semangat mitra dalam menjalankan usahanya, kegiatan sarasehan kewirausahaan dilakukan. Kegiatan ini tidak hanya terfokus pada mitra, namun juga dihadiri oleh komunitas - komunitas usaha kecil yang ada lin gkungan mitra D usun K luwih. M ateri kegiatan sarasehan kewirausahaan ini tentang pentingnya kewirausahaan, strategi - strategi kewirausahaan, dan manfaat dari kewirausahaan. H asil kegiatan ini diyakini dapat meningkatkan dan memperkuat jiwa - jiwa kewirausahaan mitra, sehingga setelah program pendampingan selesai, mitra bisa lebih man diri. 
Kegiatan pendampingan terakhir yang dilakukan adalah manajemen pemasaran. Penyuluhan manajemen pemasaran oleh mitra sangat dibutuhkan, mengingat salah satu kendala terbesar yang dihadapi mitra adalah pada aspek pemasaran. $\mathrm{H}$ al ini penting, mengingat aspek pemasaran bagi U M KM merupakan ujung tobak dalam memasarkan produk. Tujuan dari kegiatan ini adalah mitra dapat melakukan analisis potensi - potensi konsumen mereka dan strategi - strategi yang dapat dilakukan untuk memperluas cakupan pangsa pasar. Kegiatan pendampingan ini juga untuk menindaklanjuti output dari kegiatan pendampingan pembuatan logo, brosur, dan papan nama, dimana ketiga output tersebut merupakan media yang sangat membatu mitra dalam melakukan promise produknya.

Pemasaran pada hakekatnya adalah suatu komunikasi pemasaran, artinya aktifitas pemasaran yang berusaha menyebarkan informasi, mempengaruhi atau membujuk, dan atau mengingatkan pasar sasaran atas perusah aan dan produknya agar bersedia menerima, membeli dan loyal pada produk yang ditawarkan perusahaan yang bersangkutan (Tjiptono, 2008). A danya media promosi ini masyarakat lebih mengenal makanan olahan dari ikan bandeng dari I bu Eko Sayektinin gsih dan juga bandeng presto dari I bu Erni Si wi Karyanti, dan secara langsung akan meningkatkan penjualan dan lebih dikenal masyarakat luas.

U saha olahan ikan bandeng dari kedua mitra tersebut telah melakukan promosi yang diimbangi dengan kegigihan mereka setelah memperoleh pelatihan kewirausahaan dan pendampingan manajemen, akhirnya kedua mitra berhasil meningkatkan volume penjualan.

\section{SIMPULAN}

Dari kegiatan yang telah dilaksanakan maka dapat disimpulkan bahwa program IbM peningkatan kualitas produk dan pemasaran olahan bandeng ini membawa manfaat langsung bagi kedua mitra, dan manfaat tidak langsung bagi komunitas kuliner yang ada di lingkukngan pedukuhan Kluwih. Manfaat yang langsung dirasakan adalah dengan dibuatnya kemasan yang menarik maka produk dapat dipasarkan di berbagai toko kelontong dan oleh-oleh. D emikian juga ketika mitra sudah mempunyai sertifikat P-IRT produk mereka makin dipercaya oleh masyarakat dan mereka mantap untuk membeli.

M engacu pada five finger philosophy yang dikembangkan Bank Indonesia (2011) tentang pemberdayaan UMKM, hasil program pengabdian masyarakat ini mendukung upaya pemerintah dalam pemberdayaan U M K M . H al ini terlihat dengan adanya senergi yang saling menguntungkan antara U M KM , masyakarat, dan pemerintah.

Saran pada program IbM ini adalah bagi pihak mitra agar lebih serius dalam 
memanfaatkan program ini, karena program ini sangat aplikatif dan membantu peningkatan kualitas produk dan pemasaran. M elalui pendampingan manajemen, pihak mitra diharapkan semakin meningkat pemahamannya dan semakin semangat dalam mengembangkan olahan ikan bandeng tersebut.

\section{UCAPAN TERIMA KASIH}

A tas terlaksanakannya program pengabdian masyarakat ini, maka kami mengucapkan penghargaan dan ucapan terimakasih kepada:

1. Ibu Eko Sayektiningsih dan Ibu Erni Siwi Karyanti selaku mitra dalam program pengabdian masyarakat ini.

2. Dinas Kesehatan Kabupaten Kulon Progo.

3. Pengelola dan Tim Monitoring IbM Dikti.

4. Kepala LP3M U niversitas M uhammadiyah Yogyakarta.

5. M ahasiswa Manajemen FEB U MY dan semua pihak yang telah membantu dalam pelaksanaan program pengabdian masyarakat ini.

\section{DAFTAR PUSTAKA}

Bank Indonesia. (2011). Five Finger Philosophy: Upaya Memberdayakan UMKM.

Hadiyati, Ernani. (2011). Kreativitas dan Inovasi Berpengaruh Terhadap Kewirausahaan Usaha Kecil. Jurnal Manajemen dan Kewirausahaan. Vol.13, No. 1. http://dinkes.slemankab.go.id http://ejournal.uajy.ac.id/1202/5/4KOM 03409.pdf. http://jurnal-sdm. blogspot.com/2009/08/strategi-promosipenjualan-definisi.html.

J ong dan Wennekers. 2008. "Conceptualizing Entrepreneurial Employee Behavior", SMEs and Entrepreneurship Programme Finance by the Netherlands Ministry of Economic Affairs.

Koran Sindo, http://www.koran-sindo.com/node/362283.
Simamora, Henry. 2003. Memenangkan Pasar dengan Pemasaran Efektif dan Profitable, Jakarta: Gramedia Pustaka Utama.

Sudaryanto, Ragimun dan Wijayanti, R.R. (2013). Strategi Pemberdayaan UMKM Menghadapi Pasar Bebas Asean. Didownlad di https://www.kemenkeu.go.id/sites/default/ files/ strategi\% 20 pemberdayaan\%2 0 umkm. pdf. Tjiptono, Fandy. (2008). Total Quality Service, Yogyakarta: Andi Offset.

Undang-Undang Nomor 20 Tahun 2008. Tentang Usaha Mikro, Kecil, dan Menengah. 